\title{
AGRARIAN DISCOURSE OF MYKHAILO HRUSHEVSKY'S JOURNALISTIC HERITAGE: IDEOLOGY, ISSUES, RECEPTION
}

\section{Telvak V. P.}

\section{INTRODUCTION}

Mykhailo Hrushevsky's journalistic legacy is a well-studied part of his diverse works to date, as evidenced by dissertations and monographs, as well as many article publications. However, while studying numerous aspects and problems of the scholar's journalistic work, researchers pay unjustifiably little attention to the conceptual dimension of the issue, i.e., to those leading worldview ideas that determined the semantic accents of Hrushevsky's texts. Perhaps the most prominent in this regard is the sobornost ideology of the historian's work which structured all his scientific and public activities.

Therefore, we want to clarify other ideological dominants of the national service of M. Hrushevsky. After careful processing of Hrushevsky's publications, we noticed scholar's significant interest in peasantry issues. The variety, topics and amount of these texts allow us to claim that Hrushevsky consciously constructed his agrarian model - a historiographical problem that has been unnoticed so far. The author of "History of Ukraine-Rus" was a leader in the Ukrainian movement, and his ideas gained exceptional popularity among a wide range of sympathisers and opponents. Therefore, studying this multifaceted problem will allow a holistic reconstruction of an essential component of the Great Ukrainian's intellectual heritage and, in general, of the ideological discussions of the defining period of the national revival.

The source basis of our research was the various journalistic works of M. Hrushevsky of the end of the XIX - the beginning of the XX century, that discuss peasantry-related issues. These texts have been republished and commented on in the first four volumes of Hrushevsky's academic collection. Among the most valuable historiographical studies we will mention the successful attempt of Vitaliy Masnenko to find out the peasant aspects of M. Hrushevsky's historiographical heritage ${ }^{1}$, research of Svitlana Pankova $^{2}$ and Vitaliy Telvak ${ }^{3}$ on peasantry-related publishing projects of the

1 Масненко В.В. Селянство в історичній концепції Михайла Грушевського. Украӥнський селянин. 2004. № 8. С. 47-50.

2 Панькова С. Михайло Грушевський і народна газета «Село» у світлі мемуарних та епістолярних джерел. Український історик. 2004-2005. № 3-4/1. C. $25-46$. 
historian, as well as several special essays on the ideology and peculiarities of Great Ukrainian's journalism ${ }^{4}$. However, these and other studies, investigate this component of Hrushevsky's journalism superficially, which determines the relevance of our research.

\section{At the turn of the century}

At the source of M. Hrushevsky's interest in peasantry issues is Narodniks ideology that was popular among Ukrainian intellectuals of the XIX century. Mykola Kostomarov and Mykhailo Maksymovych, authoritative founders of Ukrainian academic studies, and Hrushevsky's Kyiv teachers Volodymyr Antonovych and Oleksandr Konysky were the creators of this ideology. In the end, the historian himself admitted that "when half a century later I dared to utter these theses completely to the last word [...] I only named the ideas, the views, the comparisons given by our first rector [M. Maksymovych]" ". Fully sharing the teachers' convictions, M. Hrushevsky emphasized in his inaugural lecture at Lviv University in early October 1894: "Our people connect them [periods of Ukrainian history] into one whole, and they are and must be the alpha and omega of historical research. Only the people, their ideas, challenges, struggles, haste, and mistakes are the hero of history. Our history aims to understand their economic, cultural and spiritual peculiarities, adventures, desires and aspirations" ${ }^{\prime 6}$.

M. Hrushevsky constructed historiographical discourse and his public work, particularly his journalism, following this historiosophical maxim. In its pages, the scholar has repeatedly stated that "peasantry" is the key to understanding the logic of the development of the modern Ukrainian movement. Thus, speaking on November 1, 1898, at the centenary of the revival of Ukrainian literature, $M$. Hrushevsky stressed that its primary goal

3 Тельвак В. Культурна політика Михайла Грушевського як редактора селянських газет. Украӥнський селянин. 2018. Вип. 19. С. 127-133; Telvak V., Zhuravliov S. Mykhailo Hrushevsky's editorial projects for peasants: ideology, topics, perception. Украӥнський селянин. 2020. Вип. 23. С. 78-81.

${ }^{4}$ Верстюк В. Доба Центральної Ради в публіцистичній спадщині М. Грушевського. Грушевський М. С. Твори : у 50 т. Львів : Видавництво “Світ”, 2007. Т. 4. Кн. 1. С. V-XVI. Панькова С. «...Ні хвилі не вважав себе емігрантом, тільки закордонним робітником на нашій національній ниві» (Публіцистика Михайла Грушевського доби еміграції: квітень 1919 р. - лютий 1924 р.). Грушевський М. С. Твори : у 50 т. Львів : Видавництво «Світ», 2013. Т. 4. Кн. 1. С. V-XVIII.

${ }^{5}$ Грушевський М. «Малороссійскія песни» Максимовича і століття української наукової праці. Український історик. 1984. № 1-4. С. 138.

${ }^{6}$ Грушевський М. Вступний виклад 3 давньої історії Русі. Грушевський М. С. Твори : у 50 т. Львів : Видавництво «Світ», 2002. Т. 1. С. 73. 
was to show the Ukrainian peasant an active spokesman for their people. "When people," explained the historian, "[...] instead of ethnographic studies [began] to try to focus on a Ukrainian peasant and let him speak for himself, the fate of Ukrainian literature was decided"7. Along with literature, focus on the interests of the peasantry also became a marker of the new Ukrainian historiography, a trend started by M. Kostomarov: "After wars and power struggles, the people are taking the lead, brought to the fore by the Narodniks as the bearer of the truth, the owner of priceless treasures of folk art" ${ }^{\prime \prime}$.

To understand the phenomenon of the Ukrainian peasantry, M. Hrushevsky depicts its historical evolution from one of the social strata to the main representative group of Ukrainians. Following the historiosophical rhetoric of romanticism, M. Hrushevsky writes: "After the upper classes abandoned their roots, the peasantry became the basis in the concept of Ukrainian nationality". The historian claims: "the needs and challenges of the Ukrainian peasantry are now the needs and challenges of all Ukrainians" ".

In Hrushevsky's opinion, the most important event in the history of the peasantry of the XIX century was the liberation from serfdom. As M. Hrushevsky claims, for the Ukrainian nation, represented by millions of peasants with small groups of the semi-aware intelligentsia, the abolition of serfdom opened prospects for education, culture, universal and national interests that eventually led to significant conscious changes. The scholar emphasizes that without the emancipation of the peasantry, "the results of national development achieved in fifty years would be impossible" $"$.

Diagnosing the situation of the modern peasantry, M. Hrushevsky compares his life in the Austro-Hungarian and Russian empires. Despite the mental, religious and economic differences, the scholar notes similar problems that Ukrainian peasants on both sides of Zbruch faced daily. The peasant population mainly was landless, economically dependent on large landholdings and was under the oppression of bureaucratic power, privileged nobility and extensive landholdings. Thus, national persecution was

${ }^{7}$ Грушевський, М. Українсько-руське літературне відродження в історичнім розвої українсько-руського народу. Грушевський М. С. Твори : у 50 т. Львів : Видавництво «Світ», 2002. Т. 1. С. 115.

${ }^{8}$ Грушевський, М. Українська історіографія і Микола Костомаров. Грушевський М. С. Твори : у 50 т. Львів : Видавництво «Світ», 2005. Т. 2. С. 405.

9 Грушевський М. Справа українських катедр i наші наукові потреби. Грушевський М. С. Твори : у 50 т. Львів : Видавництво «Світ», 2002. Т. 1. С. 458.

${ }^{10}$ Грушевський М. Два ювілеї. Грушевський М. С. Твори : у 50 т. Львів : Видавництво «Світ», 2005. Т. 2. С. 420. 
exacerbated by economic and cultural oppression, and throughout the Ukrainian territory, the national problem was inextricably intertwined with socio-political and economic issues. Summing up his observations, M. Hrushevsky emphasizes: "The Ukrainian element is not only a separate nation, but also, to a large extent, a separate class - a class of small rural owners, that needs socio-political and economic reforms at least in order to implement those civic and national rights already recognized for them on paper"11.

To implement his beliefs into practice, M. Hrushevsky turns to journalism, opening a discussion about necessary reforms and justifying the need for immediate action. He started with initiatives concerning Galician lands. When Hrushevsky emigrated to the constitutional Austria-Hungary, he discovered a well-established Ukrainian public life. However, the scholar noted that the leaders of the Galician political circle did not pay enough attention to the needs of the peasantry. At that time, the peasantry accounted for, according to historians, $2,885,000$ or $93.7 \%$ of all Ukrainians in the Danube monarchy. Galician leaders chose to neglect the interests of the peasantry as they were unwilling to exacerbate the conflict with the owners of the region, the Poles. Most of the land was in the hands of representatives of the Polish nobility. Thus, the agrarian issue inevitably acquired distinct features of interethnic struggle.

Having been particularly well versed in the problems of the genesis of the Polish-Ukrainian confrontation in Galicia, M. Hrushevsky defended the right of Ukrainians to equal governance with the Poles and proved the maturity of cultural and political demands of compatriots. Assessing the nature of Polish-Ukrainian relations, the scholar noted that in the environment of the constitutional state, Austria-Hungary, "Galicia became a touchstone for Polish-Ukrainian relations". The system of governing Galicia, which developed in the XIX century, opposed the national interests of the Ukrainian population. After gaining the trust of the central Austrian government, the Polish aristocratic circles gained control and power. In his articles attributed to this problem, Hrushevsky identified three main issues that triggered the Polish-Ukrainian confrontation: the agrarian issue, electoral reform, the problem of the Ukrainization of public education. Those problems were not solved during the last decades of the 19th century. Without solving them, as the Lviv professor rightly noted, the full-fledged cultural and national development of the Ukrainians of Austria-Hungary was impossible.

11 Грушевський М. Українці. Грушевський М. С. Твори : у 50 т. Львів : Видавництво «Світ», 2005. Т. 3. С. 90. 
As a part of his solution to the agrarian issue, M. Hrushevsky initiated creating a state land fund by buying land from large landowners and sharing it with small farmers. According to his vision, this initiative should have improved welfare and significantly reduced interethnic antagonism in the region. The Ukrainian publicist also encouraged reforming the electoral legislation. He suggested introducing universal suffrage to replace voting curia. As M. Hrushevsky claimed, this reform would have allowed Ukrainians to finally become the real masters of their land due to a significant increase in representation in the local parliament. Reacting to the accusations of Polish publicists about the insufficient political culture of "Rus peasants", the historian noted the considerable public consciousness of Ukrainian peasants. Carefully following their opposition to Polish domination, M. Hrushevsky stressed that "the struggle for universal and direct suffrage and parliamentary elections revealed among the peasantry firm political consciousness, strong organizational tact, vigorous public energy, unexpected until recently from an «ignorant rustic»" $" 12$.

According to the historian, the educational issue was especially relevant for the Ukrainian peasant. Analysing the current state of Galician schooling deteriorated by Polish ruling in all spheres of life, M. Hrushevsky appeals to the legal foundation of the Austrian state. He reminded his Polish opponents that paragraph 19 of the 1867 Constitution recognises the equality of all languages in education and guarantees every nationality the right to study in their native language ${ }^{13}$. However, the Polish political leadership adopted new amendments to national laws, which enforced the dominance of the Polish language and Poles in the educational sphere of Galicia. Among the shortcomings of this situation, M. Hrushevsky first notes the appointment of Polish teachers in rural schools with a predominant Ukrainian population, contrary to didactic requirements ${ }^{14}$. In such schools, the scientist argues, after analysing numerous facts, Polish teachers are engaged not so much in the education as in the denationalisation of the Ukrainian younger generation, resorting to completely non-pedagogical and often openly criminal acts.

M. Hrushevsky proposed a resolution of such a problematic situation by establishing private Ukrainian public schools, claiming that "we will never

12 Грушевський М. Українці. Грушевський М. С. Твори : у 50 т. Львів : Видавництво «Світ», 2005. Т. 3. С. 117.

13 Грушевський М. Листи 3 над Полтави. Лист третій. Грушевський М. С. Твори : у 50 т. Львів : Видавництво «Світ», 2002. Т. 1. С. 165.

${ }_{14}$ Грушевський М. Шкільна справа в Галичині. Грушевський М. С. Твори : у 50 т. Львів : Видавництво «Світ», 2005. Т. 3. С. 393-394. 
have too many of these schools"15. Calling on Galician citizens to donate to this noble cause, the scholar argued that "the creation of a national school is one of the strongest guarantees of national revival"16. The historian encouraged not just the formal nationalization of the public school with a mere introduction of the Ukrainian language of instruction but called for the adaptation of the entire curriculum to "the needs of Ukrainian society, its life, its challenges and circumstances".

Polish observers of M. Hrushevsky's public activity were unequivocally hostile to his proposals to make life easier for the Ukrainian peasant, as this should have happened at the expense of a significant restriction of the Polish "prawo posiadania". The scholar was accused of political campaigning and even instigating resistance to the established Galician order. The Polish press did not hesitate to label the respected scholar a "political dilettante", "leader of the scientific and political radicalism of the Galician Ruthenians", "a socialist by conviction", and even a "Haidamaks" herald"17.

M. Hrushevsky also devoted his attentive and insightful journalism to understanding the life and challenges of a Dnipro peasant. As soon as the Russian Empire proclaimed constitutional freedoms, the scholar immediately plunged into political life, offering solutions to many pressing issues for Ukrainians. The focus of the historian's journalism addressed to the Russian reader was the problems of the peasantry as the representative of Ukrainians. The problems became especially acute following the events of early 1906, after the elections to the First State Duma in Russia. The Ukrainian Parliamentary Community (UPC), comprised of 45 deputies, joined the first Duma. The UPC was composed of representatives of different political views and social statuses united by a desire to improve the situation in Ukraine. The majority of the UPC intelligentsia belonged to the Kadet Party, and many representatives of the peasantry belonged to the Trudovik faction. Therefore, it was not easy to consolidate such a diverse parliamentary community despite belonging to a common national platform, and M. Hrushevsky strived to unite such a diverse political group. The arrival of the historian in the Russian capital was crucial for the Ukrainian deputies of the First Duma. Dmytro Doroshenko, a witness and participant in those events, wrote: "We all viewed Hrushevsky as the leader of the Ukrainian national movement in Russia. His outstanding scientific and public merits, extraordinary organizational talent ensured his great authority and our deep respect. He was a symbol of all-Ukrainian unity, and his word was the

${ }^{15}$ Грушевський М. За рідну школу. Грушевський М. С. Твори : у 50 т. Львів : Видавництво «Світ», 2005. Т. 3. С. 78.

${ }^{16}$ Ibid. C. 69.

17 Тельвак В. Постать Михайла Грушевського в польській історіографії (кінець XIX-XX ст.). Украӥнський історичний журнал. 2006. № 5. С. 67-82. 
law for us at that time. He was in the prime of his life, full of energy and bold plans. With Hrushevsky's arrival in St. Petersburg, everyone obeyed him unconditionally, and he became the ideological leader of both the editorial board of the "Ukrainian Herald" and the Ukrainian parliamentary community"18.

As most UPC members were representatives of the peasantry, M. Hrushevsky focused on political counselling of newly elected parliamentarians. Following active communication, the scholar claimed that among them were "indeed very intelligent and conscious people, but most of them became ambassadors quite by accident and are only beginners in political education" 19 . M. Hrushevsky established effective communication with the peasantry. UPC meetings with the participation of a Lviv professor became a political school for them. Hrushevsky was delighted that many conscious Ukrainians among the peasant deputies were ready to defend national postulates. M. Hrushevsky noted with noticeable pride: "[...] The Ukrainian peasantry shows such an insightful - despite circumstances of their lives - judgement, political and social knowledge and civic education, that it should dispel any pessimistic ideas about the future of Russian Ukraine in better constitutional circumstances"20.

Given the dominance of peasants in the UPC, M. Hrushevsky prioritised the solution of the agrarian issue. No other people of the Romanov empire, the historian emphasized, was more interested in its solution than the Ukrainians. According to M. Hrushevsky, "the national motive is greatly linked to the motives of a general democratic nature" ${ }^{\text {21 }}$. Most landless peasants were Ukrainians, and large landowners were Russians, Poles or Russified compatriots. Therefore, according to the scholar, a solution to the land issue alone "will give the Ukrainian people back what was stolen from it, will make amends for the inflicted damage, will become an act of historical justice for Ukrainians"22.

M. Hrushevsky traditionally connected the agrarian issue with the national one. According to the scientist, the solution should be implemented stage by stage. First, the Duma must adopt a general imperial law on forced expropriation, in the interests of farmers, of all kinds of land surpluses, whether for ransom or without it. Then these surpluses should have constituted a land fund that would distribute the land to the peasants. Local authorities should have

18 Дорошенко Д. Мої спомини про давнє минуле 1901-1914. Вінніпег, Манітоба, 1949. С. 83.

${ }^{19}$ Грушевський М. У українських послів Російської Думи. 3 біжучої хвилі. Київ, 1907. C. 54.

${ }^{20}$ Ibid. C. 55.

${ }^{21}$ Грушевський, М. Аграрне питання. 3 біжучої хвилі. Київ, 1907. С. 99.

${ }^{22}$ Ibid. C. 101. 
organised land committees. Their primary task would have been the organisation of land measuring, considering economic and ethnographic factors. At the same time, M. Hrushevsky warned: "We should prevent the creation of a general imperial land fund, because it will strengthen the centralisation of the state"23. $\mathrm{He}$ also drew attention to the fact that the agrarian issue should be resolved simultaneously with the decentralization of the state on the principles of regional and national-territorial autonomy. The scholar tried to convince the representatives of the peasantry that only the federal system will provide a fair solution to the agrarian issue. Despite the advantages of M. Hrushevsky's agrarian project, it never became the subject of parliamentary debates of either the first or the next convocation, although Ivan Franko predicted that the project was likely to spark controversy because of its "radical principle and moderate [...] implementation" 24 .

The dissolution of the First Duma was a severe blow to all conscious Ukrainians as lawlessness once again reigned in the country. From the failures of the Ukrainian faction of the First Duma, M. Hrushevsky formulated "a self-evident axiom that purely political national work is almost impossible when it does not rely on cultural work. That without a well-organised press, popular and informational publications and systematic raising awareness about our challenges and tasks, purely political agitation is impossible, success is impossible neither in the organisation, nor in the fulfilment of political agenda [...] We will need better and stronger press, more educational and cultural organisations, and above all a stronger organisational spirit than before" 25 .

Substantiating the need for the Ukrainian mass press in the Dnipro region, M. Hrushevsky emphasised the importance of educational work in the countryside. Only the multi-million peasantry, in his opinion, was the reliable force that the activists of the Ukrainian national liberation movement could count on for support. However, in the early twentieth century, most of the peasantry remained nationally unconscious. M. Hrushevsky sought to awaken its national feelings with his publishing activity. He insisted: "We also need organisations for the distribution of Ukrainian books in the countryside, we need a friendly intelligentsia already accustomed to the Ukrainian literature in the villages. It would spread the Ukrainian literature and engage rural readers. Finally, it is necessary that Ukrainian literature answer vital political, social, economic, economic questions, which are

${ }^{23}$ Грушевский М. Вопрос дня. Украинский вестник. 1906. Вип. 2. С. 81.

${ }^{24}$ Франко І. Українська трибуна в Росії. Літературно-науковий вісник. 1906. Вип. 35. С. 337.

25 Грушевський М. Після думи. Грушевський М. С. Твори : у 50 т. Львів : Видавництво «Світ», 2002. Т. 1. С. 372. 
already rising among the educated peasantry. With the further development of freedom and political life in Russia, they will speak up more and will be more powerful. Otherwise, the Ukrainian village will remain as far from the Ukrainian literary movement as the Russian village from the recent great Russian literature", M. Hrushevsky claimed ${ }^{26}$. These lines reflect the main directions of historian's public activity in relation to the peasantry, which he tried to implement.

The illustrated weekly "Village" ("Selo"), founded by M. Hrushevsky and published in September 1909, aimed at promoting educational work. The newly created newspaper had a clear pro-peasant and popularizing orientation. It provided information on events in Ukraine and abroad in an easy and accessible form. M. Hrushevsky emphasized that the "Village" is for people "who have neither the time nor the ability to read large daily newspapers," and they "could learn from this small newspaper in short and simple words in their own language about everything important happening around them" ${ }^{, 27}$. The scholar involved selected literary activists from Ukraine to cooperate in the newspaper "Village". Among the collaborators were V. Vynnychenko, A. Krymsky, V. Samylenko and others. During the existence of the newspaper, M. Hrushevsky himself published 84 articles in it. Mykhailo Kotsyubynsky praised the publication of the first issue of Village, noting in a letter to M. Hrushevsky: "I have just read the first issue of Village and I hasten to share my impressions with you. And they are the best. The issue is very interesting, the articles are easy to read, talentedly written and are an interesting read. Presentation and illustrations make the best impression. We have never had such a great newspaper for peasant audience. We congratulate you and everyone who cares about this great goal that was only a dream before (a good newspaper for peasant audience). Now it has finally come true." 28 [Underline by M. Kotsyubynsky - author].

As expected, the authorities did not like the social and national message of the newspaper. The publication was under the watchful eye of censors. M. Hrushevsky's close participation in the "Village" drew the attention of the Kyiv gendarmerie. The "Village""s faced numerous challenges throughout its existence until February 1911. "Exactly a year and six months have passed since we began to publish this newspaper, wanting to do our best to educate and raise awareness among our people," M. wrote in the final issue to readers. "We diligently did our work, but it became harder and harder to continue.

\footnotetext{
${ }^{26}$ Грушевський М. Українство і питання дня в Росії. 3 біжучої хвилі. Київ, 1907. С. 17.

${ }^{27}$ Грушевський М. До читальників. Грушевський М. С. Твори : у 50 т. Львів : Видавництво «Світ», 2005. Т. 3. С. 287.

${ }^{28}$ Гісцова Л., упор. Листи Михайла Коцюбинського до Михайла Грушевського. Записки НТШ. 1992. Т. ССXXIV. С. 292.
} 
It is difficult now to publish independent press in general, and it is even harder to issue it in Ukrainian, and it is even more challenging to publish it for peasant audience" ${ }^{29}$. In these concluding lines, the scholar expressed his grief for the persecuted Ukrainian press. After the final closing of the newspaper, M. Hrushevsky once again expressed his sincere concern that "the loss of an organ that managed to gain a good reputation and trust of our peasant is truly unfortunate for our young and not yet rich national life" ${ }^{\text {"30 }}$.

Despite the arbitrariness of censorship, brutal harassment in the Russian chauvinist press, and annoying police surveillance, M. Hrushevsky did not stop publishing activities aimed at the peasant audience. He began to issue a new newspaper, "Zasiv", published during 1911-1912. To reduce authorities' oppression of the new newspaper, M. Hrushevsky handed over the editorial board to a group of Ukrainian writers. However, the change of board did not stop the fines and prohibitions newspaper suffered from since the first day. The issues of both publishing projects of the Lviv professor were quite similar. The authors of the newspapers urged their readers to solve their problems pro-actively, campaigned for native language education, explained the benefits of rural cooperation and the introduction of modern agricultural practices, and many more.

As was the case with Polish public commentators M. Hrushevsky, Russian publicists also treated it with caution. The agrarian initiatives of the historian aimed at transferring the lands of large owners to the Ukrainian peasantry caused an indignant uproar. The scholar was accused of propagating socialist ideas and inciting the peasantry to revolt ${ }^{31}$. M. Hrushevsky's publishing projects faced even greater conflict on the part of the authorities. As one of the scholar's assistants, Yuriy TyshchenkoSiriy, wrote to Hrushevsky in Lviv: "In many places, the "Village" is considered an illegal newspaper. And the governor of Ekaterinoslav even asked the governor of Kiev whether "Village" is really allowed, or whether this newspaper is clandestine",32.

${ }^{29}$ Грушевський М. До наших читачів. Грушевський М. С. Твори : у 50 т. Львів : Видавництво «Світ», 2005. Т. 3. С. 280.

${ }^{30}$ Грушевський М. Недооцінюваннє. Грушевський М. С. Твори : у 50 т. Львів : Видавництво «Світ», 2005. Т. 2. С. 188.

31 Тельвак В. «Ересиарх украинского движения» (рецепція творчої спадщини М. Грушевського в російському правомонархічному середовищі першої третини XX ст.). Історіографічні дослідження в Україні. 2010. Вип. 20. С. 131-154.

32 Панькова С. Михайло Грушевський i народна газета «Село» у світлі мемуарних та епістолярних джерел. Украӥнський історик. 2004-2005. № 3-4/1. С. 42. 


\section{Ukrainian War of Independence}

The outbreak of the First World War and subsequent revolutionary events made significant adjustments to the creative laboratory of Hrushevsky, a publicist. During 1917-1919 a historian constructed the ideology of the Ukrainians and tried to implement his proposals as events that dramatically changed the map of Europe unfolded. M. Hrushevsky chose journalistic speeches in periodicals as a critical tool for influencing the consciousness of contemporaries. The author compiled the most important and famous speeches in thematic brochures published in large numbers. It resulted in a significant prevalence and influence of the visions of the chairman of the Central Council.

The February Revolution broke out when M. Hrushevsky was in exile in Moscow. Despite being supervised by the police, he launched a rather rapid scientific, publishing, social and cultural work $^{33}$. As the military and revolutionary events complicated the communication, the historian learned from newspapers about a coordination inter-party centre formed by Kyiv Ukrainians, named the Central Rada. Its creators unanimously approved the candidacy of M. Hrushevsky for the head of this public association. They relied on his extraordinary talents as an organizer and moderator in settling ideological disputes. Recalling the events of that time, Dmytro Doroshenko wrote: "Seeing how difficult it was to agree, listen and work together, both sides had high hopes for the arrival of prof. M. Hrushevsky, who was expected to arrive from day to day. The position of the chairman of the Central Council was reserved for him. His personal and public authority, respected in all Ukrainian circles, was hoped to reconcile all contradictions and unite everyone to work together for the public good" 34 .

Once in Ukraine, M. Hrushevsky expertly diagnosed the greatest threat to the Ukrainian movement at that time - the significant atomization of its leaders and members. Therefore, he rapidly developed a new unifying ideology for Ukrainians, which faced the relevant challenges and part ways with the old cultural slogans. At the same time, he, using solid prerevolutionary experience ${ }^{35}$, did his best to build a network of Ukrainian media. Without them, it was not possible to spread the ideology of the new Ukrainians outside of Kyiv. In the pages of renewed and newly created journals (Nova Rada, Literary-Scientific Herald, News from the Ukrainian

33 Пиріг Р.Я., Тельвак В.В. Михайло Грушевський : біографічний нарис. Київ : Либідь, 2016. С. 259-269.

${ }^{34}$ Дорошенко Д. Мої спомини про недавнє-минуле (1914-1920). Мюнхен, 1969. C. $86-87$.

35 Тельвак В. Культурна політика Михайла Грушевського як редактора селянських газет. Украӥнський селянин. 2018. Вип. 19. С. 127-133. 
Central Rada in Kyiv), he shared his understanding of current challenges and offered solutions. M. Hrushevsky's journalism, published on the pages of Kyiv publications, was promptly circulated by provincial newspapers and actively shared by the Ukrainian foreign press.

Moreover, the most popular texts were reprinted in several famous pamphlets. Their demand is eloquently evidenced by the solid circulations as cited by the authoritative bibliographic journal "Knigar". The first edition of the brochure "What kind of autonomy and federation we want" was published in 20 thousand copies, the second one in 30 thousand. The first and second editions of the collection of articles "Who are Ukrainians and what do they want" had a circulation of 30,000 copies. The first and second editions of the book "Where did Ukraine come from and what is its goal" 30 thousand copies. The brochure "Ukrainian Central Rada and its Universals: the First and the Second" was published with a circulation of 13.5 thousand copies $^{36}$. Therefore, we have every reason to claim about the considerable demand and influence of the journalistic speeches of the Chairman of the Central Rada. Contemporaries of the scholar also wrote about their popularity, noting that among the activists of the Ukrainian parliament, "there was no shortage of educated people or historians, but none of them was equal to M. Hrushevsky in the ability to hone his historical worldview to current events" ${ }^{, 3}$. In our opinion, we should fully agree with V. Verstyuk's observation that the popularity of M. Hrushevsky's journalism at that time ensured by the fact that it performed two important functions at once: campaigning and propaganda as well as conceptual and ideological ${ }^{38}$.

Writing about the need to mobilise Ukrainians, the head of the Ukrainian parliament calls for conscious and dynamic self-organization of all groups. At the same time, he prioritises the consolidation of the peasantry as a quantitatively dominant stratum, which in his view, was the primary sociocultural basis for the development of Ukrainian statehood. M. Hrushevsky convinced his readers that "[...] in the end, everything - freedom, and revolution, and the will of Ukraine, and the land - depends on what our people and especially peasantry will be like: a pile of sand scattered by a single gust of wind or a solid foundation that a free, autonomous people of Ukraine can rely on"39.

\footnotetext{
${ }^{36}$ Книгар. 1918. Ч. 5 (Січень). С. 246.

37 Єреміїв М. За лаштунками Центральної Ради. Грушевський М. С. Твори : у 50 т. Львів : Видавництво «Світ», 2007. Т. 4. Кн. 1. С. 103.

38 Верстюк В. Доба Центральної Ради в публіцистичній спадщині М. Грушевського. С. VIII-IX.

${ }^{39}$ Грушевський М. Велике діло. Грушевський М. С. Твори : у 50 т. Львів: Видавництво «Світ», 2007. Т. 4. Кн. 1. С. 35.
} 
Therefore, the chairman of the Central Rada dedicated his journalism to raising the political awareness of the broad audience. His texts provided various recommendations on civil self-organization. In numerous texts, Hrushevsky tirelessly repeated - "in the village, an elected village council should rule all major decisions" $" 40$. Educational work became incredibly intensive with the appearance of the new daily peasant newspaper "People's will" ("Narodna Volya"). In the first issue, M. Hrushevsky emotionally raised the importance of the appearance of a new media tribune for the broadest masses: "I am happy, my peasant brothers, that I can speak to you in the pages of a large, daily people's newspaper. This has always been my dream, and it took a revolution for the tsarist government to fall, and all the violence associated with it for the opportunity to arise. Nothing terrified this tsarist government, or the old regime, as it is called, more than popular educational and political literature and the press (newspaper). It believed and was right - that as soon as the Ukrainian printed word, science, education in a language understood by the Ukrainian people, reached wide Ukrainian circles, its domination in Ukraine will end" ${ }^{41}$.

M. Hrushevsky intended the new newspaper to become a kind of a "club" for peasant audience. Another more important task was to establish communication with other strata of Ukrainian society. He aimed at establishing a trusting dialogue between peasants and members of the intelligentsia. The tsarist administration had successfully destroyed this connection through a system of numerous prohibitions and the cultivation of many stereotypes about incompatibility between the intelligentsia and peasants. Despite these obstacles, M. Hrushevsky informed the reader that the intelligentsia never renounced its peasant roots, cultivating folk culture on any occasion. "Thus," says the historian, "the ground was being prepared for a new Ukrainianness" $"$. Therefore, since the beginning of the revolution, when all prohibitions were finally lifted, Ukrainians faced the challenge to restore unity. "The opportunity has come to unite", the chairman of the Central Rada emphasized, "to understand, organize and join the people - the peasantry, workers, soldiers and intellectuals - to bring good to their land and people",43.

40 Грушевський М. Хто такі українці і чого вони хочуть. Грушевський М. С. Твори : у 50 т. Львів : Видавництво «Світ», 2007. Т. 4. Кн. 1. С. 158.

${ }^{41}$ Грушевський М. Кінець старому лукавству. Грушевський М. С. Твори : у 50 т. Львів : Видавництво «Світ, 2007. Т. 4. Кн. 1. С. 28.

42 Грушевський М. Звідки пішло українство і до чого воно йде. Грушевський М. С. Твори : у 50 т. Львів : Видавництво «Світ», 2007. Т. 4. Кн. 1. С. 172.

${ }^{43}$ Грушевський М. Кінець старому лукавству. Грушевський М. С. Твори : у 50 т. Львів : Видавництво «Світ», 2007. Т. 4. Кн. 1. С. 29. 
To achieve this goal, M. Hrushevsky dedicated meticulous attention to the work of the First All-Ukrainian Peasants' Congress in Kyiv in late May-early June 1917. The Congress united up to 2,500 delegates (1,500 with the right for a deciding vote, the rest - with an advisory). Together they represented all 9 Ukrainian provinces, as well as the Kuban and Don regions. In total, there were representatives from 73 counties and more than 1,000 parishes, mainly from peasant unions ${ }^{44}$. The chairman greeted the participants on behalf of the Central Council. He raised the importance of the organizational unity of the peasantry for the further progress of the Ukrainian revolution. As the historian emphasised, the delegates elected by the congress would enter the parliament, giving it the necessary legitimacy. As a result of his welcoming speech, M. Hrushevsky once again voiced his conviction about the peasant nature of Ukrainians: "We shouldn't take offence in being called "the peasants' nation", on the contrary, let us take pride in it. As most of our people are peasants, we must pursue our national policy following the interests of the peasantry. Therefore, the peasantry needs to know that the Ukrainian intelligentsia and the Central Ukrainian Rada want to establish a system that would ensure the interests of the working people, and therefore the Central Rada must heed them achieve what our people need" ${ }^{\text {"45 }}$.

After this speech, the delegates applauded M. Hrushevsky as the honorary chairman of the peasant forum, which eloquently testified to the great authority of the scientist among the people. One of the important results of the congress was the election of the All-Ukrainian Council of Peasant Deputies. The council entered the Central Council as a representation of the Ukrainian peasantry. The last decision was personally supported by M. Hrushevsky, who arrived at the congress at the end of the election. He read a telegram from the chairman of the Ukrainian National Council in Petrograd Petro Stebnytsky, who informed about the refusal of the Provisional Government to issue an act on the autonomy of Ukraine ${ }^{46}$. The Speaker of the Parliament asked to speed up the elections so that the newly elected Council of Peasants' Deputies would immediately take part in the emergency session of the Central Rada, which was postponed until the arrival of the representatives of the peasantry. Leaving the congress,

44 Хміль І.В. Перший Всеукраїнський селянський з’їзд (28 травня - 2 червня 1917 р.). Історичні зошити. 1992. № 4.

45 Грушевський M. [Промови на I Всеукраїнському селянському з’їзді у Києві...]. Грушевський М. С. Твори : у 50 т. Львів : Видавництво “Світ”, 2007. T. 4. Кн. 1. С. 33.

46 Перший Всеукраїнський селянський з’їзд. Нова рада. 1917. 4 червня. № 55. C. 2 
M. Hrushevsky stressed: "[...] I hope that you will soon finish the elections of the Council of Peasant Deputies and together with the Central Council your representatives will decide what to do next. We need the autonomy of Ukraine, it must be achieved..."47. Delegates greeted these words with loud applause and cheering: "Long live free Ukraine!".

The evening meeting of the Central Council opened the same day at 6 p.m. The Council of Peasant Deputies was already present in its entirety. Welcoming them in the parliament, M. Hrushevsky stressed that together they would "be in charge of the peasant organization, land affairs and in general everything related to the affairs and interests of the peasantry"48. As is well known, the Central Rada, enriched by peasant representation, soon proclaimed the First Universal, thus initiating the formation of Ukrainian statehood. Somewhat later, recalling these events, M. Hrushevsky noted that the Peasants' Congress "revealed pro-active political and national consciousness among the Ukrainian peasantry, contrary to the stereotype about the peasant "darkness". It is about new solidarity and unshakable trust in our national representation, the Ukrainian Central Rada"49.

Some observers of Ukrainian life made harsh comments about the peasant movement being fabricated. They claimed that Ukrainian peasants were uneducated, inert and did not relate to slogans put forward by the ideologues of the Central Rada. M. Hrushevsky resolutely defended the people's representatives who took the initiative to join the latest state formation. In numerous journalistic texts, he praised the considerable wisdom of Ukrainian peasants, their excellent understanding of the revolutionary situation and a deep awareness of responsibility for future generations. The chairman of the Central Rada emphasized: "Ukrainian peasants, who, in the first months of the revolution at various meetings and congresses discussing democratic republic, insisted that it should be a federal republic, were not echoing someone else's ideas, as some believed. Long before that, they learned the ideas of political autonomy and the idea of the federation from popular Ukrainian literature" ${ }^{, 50}$.

47 Грушевський М. [Промови на I Всеукраїнському селянському з’їзді у Києві...]. Грушевський М. С. Твори : у 50 т. Львів : Видавництво «Світ», 2007. Т. 4. Кн. 1. С. 33.

48 Грушевський М. Велике діло. Грушевський М. С. Твори : у 50 т. Львів : Видавництво «Світ», 2007. Т. 4. Кн. 1. С. 35.

${ }^{49}$ Ibid. C. 44.

50 Грушевський М. Промова М.С.Грушевського від імені українських організацій, проголошена 10 вересня [1917 р. на 3 з’їзді народів у Києві]. Грушевський М. С. Твори : у 50 m. Львів : Видавництво «Світ», 2007. Т. 4. Кн. 1. C. 60 . 
In a short time, the Central Rada started implementing the most needed solutions to issues peasants faced. On January 18, 1918, at the insistence of the Socialist-Revolutionary majority, the parliament passed the Provisional Land Law, which was quite radical. It was based on the principle of socialization of land, its separation from large farms. Such formulation of the law did not help stabilize the political situation in Ukraine. As researchers rightly point out, on the one hand, it strengthened the illusions of the poor part of the peasantry, fuelled anarchic sentiments, and on the other, provoked the outrage of large landowners and wealthy peasants who traditionally owned private property in Ukraine since Cossack times. The USDLP, UPSF and UPSI factions in the Central Rada insisted on revising the law. However, M. Hrushevsky, the informal leader of the Ukrainian Socialist Revolutionaries, supported the law and justified its expediency in several journalistic speeches ${ }^{51}$.

The implementation of land reform was far from perfect. During MarchApril 1918, a lot of estates and sugar plantations were transferred to the land committees. However, the distribution was slow, and many lands were left without owners. The peasantry did not have stock, seeds, and sometimes the desire to cultivate the land. Landowners were forbidden to sow in the spring. Accordingly, the future harvest and Ukraine's ability to meet its economic obligations to its military allies depended on spring fieldwork. As a result, the growing uncertainty in the commitments of the Ukrainian authorities turned the allies into occupiers. M. Hrushevsky himself perfectly understood the hopelessness of the Central Rada's situation, but he could only try to influence the peasantry with his journalism. Thus, at the Kyiv Peasant County Congress, which took place on April 7, 1918, he quite emotionally persuaded the delegates: "This may be the last time for us to prove our state wisdom. For if we do not establish power now, if we do not now establish a firm and good order, and our fields remain unsown, and we do not keep our state, we will be cursed by our descendants. But I hope that you will take all measures so that this does not happen, so that all the fields are sown; and there will be order everywhere on our land, drenched in blood and sprinkled with ashes" ${ }^{\prime \prime 2}$.

Unfortunately, the circumstances were fatal for the Central Rada, as its authority was rapidly declining in the eyes of the public and recent allies.

51 Грушевський М. «Святі права». Грушевський М. С. Твори : $у 50 \mathrm{~m}$. Львів : Видавництво «Світ», 2007. Т. 4. Кн. 1. С. 127-129.

52 Грушевський М. Промова голови Центральної Ради проф. М.С. Грушевського, виголошена на Київському селянському повітовому з’їзді 7 квітня [1918р.]. Грушевський М. С. Твори : у 50 т. Львів : Видавництво «Світ», 2007. Т. 4. Кн. 1. C. 130. 
The parliament speaker increasingly criticized the comments about the failure of socialist governments to bring order to the state. Hrushevsky was hurt to learn about the Ukrainian activists of the conservative side asking the German command to change the current government. A few days before the hetman's coup, he wrote a warning article, "Old Story", in which he criticized the behaviour of his opponents, interpreted it as a betrayal of national ideals, the desire to protect their interests with the help of other people's bayonets. Anticipating a change of government, M. Hrushevsky predicted that it would lead to the destruction of the national project. Addressing the peasant reader, the historian compared the actions of these deputies with the actions of their predecessors during the Khmelnytsky Uprising: "Having achieved the proclamation and recognition of Ukrainian statehood with the help of peasants, they call on our government to turn its back on them and serve its landowners! Abolish the land reform and, relying on German bayonets, restore landlordism! This would be a letter-by-letter repetition of that grave, unforgettable shameful historical mistake that Ukraine paid for with 250 years of serfdom!" 53 .

M. Hrushevsky published his reflections about that period in "On the Threshold of the New Ukraine: Thoughts and Dreams". In the historiographical tradition, this work gained the status of the scientist's "political testament". M. Hrushevsky painted a portrait of the future state, and he paid particular attention to the prospects of the village - the "foundation of Great Ukraine". He expressed his worries that many Ukrainian politicians neglect peasant interests only because of the belief that the creator of the revolution should have been the proletariat. In agrarian Ukraine, the historian claims, its revival and further progress will be associated with the cultural achievements of the peasants for a long time to come. "I will say more, - emphasizes M. Hrushevsky, - I am deeply convinced that only those phenomena that are closely and sincerely tied to peasant masses, will stand the test of time" ${ }^{, 54}$. Therefore, the peasantry will long remain the foundation of national life. "Only those projects that keep peasants' best interests at heart will stand strong. And bad fate shall befall those movements, parties, plans and intentions that go against them - they will condemn themselves to extinction and fall apart one day once and for all", sums up the author ${ }^{55}$.

${ }^{53}$ Грушевський М. Стара історія. Грушевський М. С. Твори : у 50 т. Львів : Видавництво «Світ», 2007. Т. 4. Кн. 1. С. 134.

${ }^{54}$ Грушевський М. На порозі Нової України: Гадки і мрії. Грушевський М. С. Твори : у 50 т. Львів : Видавництво «Світ», 2007. Т. 4. Кн. 1. С. 253.

${ }^{55}$ Ibid. 
The Hetman's coup, ironically called by M. Hrushevsky an "ugly anecdote", knocked him out of active political life and prompted him to reflect deeply on the events of the Ukrainian revolution. The historian considered the role of the peasantry in those events. First and foremost, the former chairman of the Central Rada refuted the general accusations of mass support or even the organization of a hetman's coup. The historian argued that large landowners manipulated peasant rhetoric in their plans to eliminate the Central Rada's achievements and abolish the land law. On the contrary, he emphasizes, the peasants in the Directory's detachments restored the UPR. Therefore, M. Hrushevsky concluded that "and now, our peasantry, who liberated and restored Ukrainian Republic, must hold it firmly in their hands. They should keep order, harmony and unite their forces to protect it, so that, God forbid, a former Cossack officer or the current hetmans and Germans take their lands away"56.

Another critical problem was the growing apathy towards the Ukrainian movement in the peasant environment. After surviving the return of the old order under the Hetmanate, the peasants lost faith in the state as an institution that should guarantee their rights and freedoms. The historian emphasized in the article "Rehabilitation of public life" that the bodies of peasant self-government should be mobilized under such conditions. They must take over the functions of democratic institutions, which were lacking in the revived $\mathrm{UPR}^{57}$. The mentioned article became an ideological substantiation of further political steps of M. Hrushevsky and his political partners. They decided to convene the Peasant Congress of Kamenets Powiat, which took place on March 20-22, 1919.

Participation in this Congress was the last political action of M. Hrushevsky before emigrating. The forum united 106 delegates from the peasantry, two members of the All-Ukrainian Labour Congress from Podillya and two from Ekaterinoslav. The adopted resolution proclaimed the forum the Labour Congress of Kamenets Powiat. The delegates unanimously elected M. Hrushevsky as the honorary co-chairman of the Congress. He made a welcoming speech, urging the peasants to unite and work together: "There is nothing more dangerous than waiting for the leader, instructions, orders from the centre in such dangerous moments when the centre loses all influence on the current events and badly mismanages them. In these difficult circumstances, all salvation depends on the initiative of small organizations. We must be ready for a long period of revival of

${ }^{56}$ Грушевський М. Відродження Української Республіки. Грушевський М. С. Твори : у 50 т. Львів : Видавництво «Світ», 2007. Т. 4. Кн. 1. С. 25.

${ }^{57}$ Ibid. C. $31-32$. 
Ukrainian state life from these local groups. We must be ready and arm our people with appropriate means so that they emerge victorious. Let the current Peasants' Congress begin!" ${ }^{58}$. The forum elected the KamyanetsPodilsky Labour Council, which became part of the Committee for the Protection of the Republic established in those days. The congress was widely covered in the pages of the newspaper "Life of Podillya", edited by M. Hrushevsky. However, this congress had no effect on the catastrophic political situation for Ukraine, and soon the co-chairman himself left Kamenets and went to Prague, not knowing that five years of emigration were waiting ahead.

Finally, a few words about the reception of M. Hrushevsky's journalism of the revolutionary era. We have mentioned the circulation of thousands of copies that reflect a great public demand. Ukrainian observers of the historian's journalism emphasized the significant need for such publications. Hrushevsky's articles offered a new worldview in different political conditions and concisely explained current national postulates ${ }^{59}$. The Literary-Scientific Herald, for example, stated: "The need for political literature is enormous, and it is not easy to satisfy. The oppressive circumstances of the past did not allow us to prepare in advance. Now we need to create that literature using some valuable bits from the previous work. [...] However, recognizing the great importance of this case, our intelligentsia found time for that job as well. Prof. Hrushevsky shows us an example by standing at the heart of our political life and taking the most active part in it. At the same time, he managed to make a valuable contribution to our new-born political literature, paving the way for the spiritual leaders of our people, organizing them and highlighting the needs and challenges of today" ${ }^{\prime 60}$.

As expected, observers from the camp of "the one and indivisible" were openly critical. Recalling their emotional reaction to his texts, M. Hrushevsky wrote: "The enemies of Ukraine, who had long been breathing hell on me, and who, in their blindness, considered me the creator of both the Ukrainian movement and the inventor of the Ukrainian language,

58 Грушевський М.В дванадцяту годину. Грушевський М. С. Твори : у 50 т. Львів : Видавництво «Світ», 2007. Т. 4. Кн. 1. С. 37.

59 Див. докл.: Тельвак В. Творча спадщина Михайла Грушевського в оцінках сучасників (кінець XIX - 30-ті роки XX століття). Київ - Дрогобич : «Вимір», 2008. C. 184-201.

${ }^{60}$ Волох С. : Мих. Грушевський. Якої ми хочемо автономії і федерації. Вільна Україна, статті з останніх днів. Хто такі українці і чого вони хочуть. - звідки пішло українство і до чого воно йде... Київ, 1917. Літературно-науковий вістник. 1917. T. LXVII. C. 155. 
attack me with their curses and threats anew" ${ }^{\prime 61}$. Unfortunately, even former friends and defenders of the historian from Russian academic circles did not accept the new ideology of Ukrainians Hrushevsky expressed in journalism. They felt betrayed by their Ukrainian colleague after he headed the Central Rada. After all, in the pre-war period and especially in the years of his exile, liberal Russian intellectuals made considerable efforts to convince government officials of various levels (up to the President of the Academy of Sciences, Grand Duke Konstantin Romanov) in the purely cultural goal of M. Hrushevsky's diverse work. The revolutionary events proved the fears of the enemies of Ukrainians correct. They had always emphasised the danger to the empire's integrity in the Hrushevsky's public activity. The epistolary of Hrushevsky's former friend Oleksiy Shakhmatov, addressed to Russian colleagues during the revolutionary times, expressed his hurt feelings. In a letter to Anatoliy Koni, he wrote: "Like you, I am horrified by the betrayal of Ukrainians now led by Hrushevsky. This is the heaviest blow to Russia" ${ }^{, 62}$.

\section{CONCLUSIONS}

In our conclusions, we emphasise the distinct peasant-centrism of M. Hrushevsky's journalism. In his various texts (articles, speeches, appeals), the scientist acts as an insightful observer of all aspects of people's lives on both sides of Zbruch. This comprehensive analysis from a sobornost perspective gave him arguments for numerous socio-cultural initiatives aimed at snatching the Ukrainian peasant from the vicious circle of patriarchal traditions and feudal prohibitions, nudging them in the direction of modernisation paved by the western neighbours. We will also point out the crucial functions that M. Hrushevsky's journalism performed in the broad masses of the Ukrainian audience. His articles performed ideologicaleducational, informational and mobilising tasks. At the same time, the journalism had a serious tone, avoided inappropriate indulgences or didactics. On the contrary, M. Hrushevsky's journalism was stylistically constructed in a dialogical manner. In his texts, he did not instruct the peasants but consulted with them as equal partners on numerous pressing issues of national existence. Due to such openness and dialogic narrative, the journalistic appeal of the author of the "History of Ukraine-Rus" had considerable resonance, contributing to the growth of political culture in

61 Життя професора Михайла Грушевського від вибуху світової війни. Земля і Воля. 1920. № 25. С. 2.

62 Цит. за: Робинсон М.А. Судьбы академической элиты: отечественное славяноведение (1917 - начало 1930-х годов). Москва : Издательство «Индрик», 2004. C. 21. 
broad peasant circles. As a result, the agrarian ideas of M. Hrushevsky influenced the Ukrainian intellectual culture throughout the twentieth century.

\section{REFERENCES}

1. Верстюк В. Доба Центральної Ради в публіцистичній спадщині М. Грушевського. Грушевський М. С. Твори : у 50 т. Львів : Видавництво «Світ», 2007. Т. 4. Кн. 1. С. V-XVI.

2. Волох С.: Мих. Грушевський. Якої ми хочемо автономії $\mathrm{i}$ федерації. - Вільна Україна, статі з останніх днів. - Хто такі українці і чого вони хочуть. - звідки пішло українство і до чого воно йде... Київ, 1917. Літературно-науковий вістник. 1917. T. LXVII. C. 155-156.

3. Гісцова Л., упор. Листи Михайла Коцюбинського до Михайла Грушевського. Записки НТШ. 1992. Т. CCXXIV. С. 283-294.

4. Грушевский М. Вопрос дня. Украинский вестник. 1906. Вип. 2. С. 79-81.

5. Грушевський М. [Промови на I Всеукраїнському селянському з’їзді у Києві... ]. Грушевський М. С. Твори : у 50 т. Львів : Видавництво «Світ», 2007. Т. 4. Кн. 1. С. 33.

6. Грушевський М. «Малороссійскія песни» Максимовича i століття української наукової праці. Украӥнський історик. 1984. № $1-4$. С. 122-140.

7. Грушевський М. «Святі права». Грушевський М. С. Твори : у 50 т. Львів: Видавництво «Світ», 2007. Т. 4. Кн. 1. С. 127-129.

8. Грушевський М. В дванадцяту годину. Грушевський М. С. Твори : у 50 т. Львів : Видавництво «Світ», 2007. Т. 4. Кн. 1. С. 37.

9. Грушевський М. Велике діло. Грушевський М. С. Твори : у 50 т. Львів: Видавництво «Світ», 2007. Т. 4. Кн. 1. С. 35-36.

10. Грушевський M. Відродження Української Республіки. Грушевський М. С. Твори : у 50 т. Львів : Видавництво «Світ», 2007. T. 4. Кн. 1. С. 23-25.

11. Грушевський М. Два ювілеї. Грушевський М. С. Твори : у 50 т. Львів : Видавництво «Світ», 2005. Т. 2. С. 420-423.

12. Грушевський М. До наших читачів. Грушевський М. С. Твори : у 50 т. Львів : Видавництво «Світ», 2005. Т. 3. С. 280-281.

13. Грушевський М. До читальників. Грушевський М. С. Твори : у 50 т. Львів: Видавництво «Світ», 2005. Т. 3. С. 287.

14. Грушевський М. За рідну школу. Грушевський М. С. Твори : у 50 т. Львів: Видавництво «Світ», 2005. Т. 3. С. 72-79.

15. Грушевський М. Звідки пішло українство і до чого воно йде. Грушевський М. С. Твори : у 50 т. Львів : Видавництво «Світ», 2007. T. 4. Кн. 1. С. $166-180$. 
16. Грушевський М. Кінець старому лукавству. Грушевський М. С. Твори : у 50 т. Львів: Видавництво «Світ», 2007. Т. 4. Кн. 1. С. 28-30.

17. Грушевський М. Листи 3 над Полтви. Лист третій. Грушевський М. С. Твори : у 50 т. Львів : Видавництво «Світ», 2002. Т. 1. C. $153-168$.

18. Грушевський М. На порозі Нової України: Гадки i мрії. Грушевський М. С. Твори : у 50 т. Львів : Видавництво «Світ», 2007. T. 4. Кн. 1. С. 225-266.

19. Грушевський М. Наша школа. Грушевський М. С. Твори: у 50 т. Львів : Видавництво «Світ», 2005. Т. 3. С. 63-69.

20. Грушевський М. Недооцінюванне. Грушевський М. С. Твори : у 50 т. Львів : Видавництво «Світ», 2005. Т. 2. С. 181-188.

21. Грушевський М. Оздоровлення громадського життя. Грушевський М. С. Твори : у 50 т. Львів : Видавництво «Світ», 2007. Т. 4. Кн. 1. С. 31-32.

22. Грушевський М. Після думи. Грушевський М. С. Твори : у 50 т. Львів : Видавництво «Світ», 2002. Т. 1. С. 371-372.

23. Грушевський М. Промова голови Центральної Ради проф. М. С. Грушевського, виголошена на Київському селянському повітовому з 'їзді 7 квітня [1918р.]. Грушевський М. С. Твори : у 50 т. Львів : Видавництво «Світ», 2007. Т. 4. Кн. 1. С. 130-131.

24. Грушевський М. Промова М. С. Грушевського від імені українських організацій, проголошена 10 вересня [1917 р. на з з'їзді народів у Києві]. Грушевський М. С. Твори : у 50 т. Львів : Видавництво «Світ», 2007. Т. 4. Кн. 1. С. 60-64.

25. Грушевський М. Справа українських катедр i наші наукові потреби. Грушевський М. С. Твори : у 50 т. Львів : Видавництво «Світ», 2002. Т. 1. С. 450-459.

26. Грушевський М. Стара історія. Грушевський М. С. Твори : у 50 т. Львів : Видавництво «Світ», 2007. Т. 4. Кн. 1. С. 131-134.

27. Грушевський М. Треба ясніше! Грушевський М. С. Твори : у 50 т. Львів : Видавництво «Світ», 2007. Т. 4. Кн. 1. С. 44-47.

28. Грушевський М. В українських послів Російської Думи. 3 біжучої хвилі. Київ, 1907. С. 50-59.

29. Грушевський М. Українство і питання дня в Росії. 3 біжучої хвилі. Київ, 1907. С. 5-17.

30. Грушевський М. Українці. Грушевський М. С. Твори : у 50 т. Львів : Видавництво «Світ», 2005. Т. 3. С. 89-97.

31. Грушевський М. Хто такі українці і чого вони хочуть. Грушевський М. С. Твори : у 50 т. Львів : Видавництво «Світ», 2007. T. 4. Кн. 1. С. $152-165$. 
32. Грушевський М. Шкільна справа в Галичині. Грушевський М. С. Твори: у 50 т. Львів : Видавництво «Світ», 2005. Т. 3. С. 393-394.

33. Грушевський М. Аграрне питання. 3 біжучої хвилі. Київ, 1907. C. 81-99.

34. Грушевський М. Вступний виклад 3 давньої історії Русі. Грушевський М. С. Твори : у 50 т. Львів : Видавництво «Світ», 2002. T. 1. C. $63-74$.

35. Грушевський, М. Українська історіографія і Микола Костомаров. Грушевський М. С. Твори: у 50 т. Львів : Видавництво «Світ», 2005. T. 2. C. $380-409$.

36. Грушевський, М. Українсько-руське літературне відродження в історичнім розвої українсько-руського народу. Грушевський М. С. Твори: у 50 т. Львів : Видавництво «Світ», 2002. Т. 1. С. 109-117.

37. Дорошенко Д. Мої спомини про давнє минуле 1901-1914. Вінніпег, Манітоба, 1949. 543 с.

38. Среміїв М. За лаштунками Центральної Ради. Грушевський М. С. Твори: у 50 т. Львів : Видавництво «Світ», 2007. Т. 4. Кн. 1. С. 94-104.

39. Життя професора Михайла Грушевського від вибуху світової війни. Земля і Воля. 1920. № 25. С. 2-3.

40. Масненко В.В. Селянство в історичній концепції Михайла Грушевського. Украӥнський селянин. 2004. № 8. С. 47-50.

41. Панькова С. «...Ні хвилі не вважав себе емігрантом, тільки закордонним робітником на нашій національній ниві» (Публіцистика Михайла Грушевського доби еміграції: квітень 1919 р. - лютий 1924 р.). Грушевський М. С. Твори : у 50 т. Львів : Видавництво «Світ», 2013. T. 4. Кн. 1. C. V-XVIII.

42. Панькова С. Михайло Грушевський і народна газета «Село» у світлі мемуарних та епістолярних джерел. Украӥнський історик. 2004-2005. № 3-4/1. С. 25-46.

43. Перший Всеукраїнський селянський з'їзд. Нова рада. 1917. 4 червня. № 55. С. 2.

44. Пиріг Р. Я., Тельвак В. В. Михайло Грушевський: біографічний нарис. Київ : Либідь, 2016. С. 576 с.

45. Робинсон М. А. Судьбы академической элиты: отечественное славяноведение (1917 - начало 1930-х годов). Москва : Издательство «Индрик», 2004. 432 с.

46. Тельвак В. «Ересиарх украинского движения» (рецепція творчої спадщини М. Грушевського в російському правомонархічному середовищі першої третини XX ст.). Історіографічні дослідження в Україні. 2010. Вип. 20. С. 131-154. 
47. Тельвак В. Культурна політика Михайла Грушевського як редактора селянських газет. Український селянин. 2018. Вип. 19. C. $127-133$.

48. Тельвак В. Постать Михайла Грушевського в польській історіографії (кінець ХIX-XX ст.). Украӥнський історичний журнал. 2006. № 5. С. 67-82.

49. Тельвак В. Творча спадщина Михайла Грушевського в оцінках сучасників (кінець XIX - 30-ті роки XX століття). Київ - Дрогобич : «Вимір», 2008. 492 с.

50. Франко І. Українська трибуна в Росії. Літературно-науковий вісник. 1906. Вип. 35. С. 332-338.

51. Хміль І.В. Перший Всеукраїнський селянський з'їзд (28 травня 2 червня 1917 р.). Історичні зошити. 1992. № 4. С. 15-25.

52. Telvak V., Zhuravliov S. Mykhailo Hrushevsky's editorial projects for peasants: ideology, topics, perception. Украӥнський селянин. 2020. Вип. 23. С. 78-81. 